\title{
Antalya İlinde Turizme Açık Doğal Alanların Tehlike Düzeylerinin Bütünleşik SWARA-MOORA Yöntemi ile Belirlenmesi
}

\section{Determination of Hazard Levels of Natural Areas not Opened for Intensive Use in Tourism in ANTALYA Province with Hybrid SWARA-MOORA Technique}

\author{
Onur SELÇUK ${ }^{1} \oplus$, Hatice KARAKAŞ ${ }^{1}$, Emre İPEKÇİ ÇETİN² ${ }^{\oplus}$ \\ ${ }^{1}$ Akdeniz Üniversitesi, Turizm Fakültesi, Turizm İşletmeciliği, Antalya, Türkiye \\ ${ }^{2}$ Akdeniz Üniversitesi, İktisadi ve İdari Bilimler Fakültesi, Ekonometri, Antalya, Türkiye
}

ORCID: O.S. 0000-0003-2818-2291; H.K. 0000-0001-5893-1199; E.İ.Ç. 0000-0002-8108-1919

\section{öz}

Turizm ve doğal çevre ilişkisinin sürdürülebilir olabilmesi için var olan doğal alanların korunması gerektiği ortadadır. Çevresel sorunlara sahip bir destinasyonda turizm faaliyetlerinin gelişimi olası değildir. Bu çalışmada Antalya ilinde turizm amaçlı ziyaret edilen doğal alanlarda oluşan çevresel tehlike düzeyinin belirlenmesi amaçlanmaktadır. En fazla tehlike altında olan ve korunmaya en muhtaç doğal alanların belirlenmesi için bu çalışmada çok kriterli karar verme yöntemlerinden faydalanılmıştır. Bu maksatla Antalya ilinde yer alan ve yoğun kullanıma açılmamış 15 doğal alan ve bu doğal alanları tehlikeye atacağı düşünülen 8 kriter belirlenmiştir. Çalışmada SWARA ve MOORA yöntemleri bütünleşik olarak kullanılmıştır. SWARA yöntemiyle kriterlerin ağırlıkları belirlendikten sonra MOORA yöntemiyle doğal alanların tehlike düzeyleri sıralanmıştır. Doğal alanların tehlike düzeyini gösteren kriterler arasında en önemli kriterlerin "kirlilik düzeyi" ve "taşıma kapasitesi" olduğu, en az etkiye sahip kriterin ise "su kaynağına yakınlık" olduğu tespit edilmiştir. MOORA Oran Yöntemi ve MOORA Referans Yöntemi sonuçlarına göre en fazla tahribata uğrayan, olası tehlike düzeyi en yüksek olan doğal alanlar kıyı kesimlerinde yer alan Korsan Koyu, Gizli Koy ve Ceneviz Koyu'dur. Ele alınan alternatifler arasında en az tehlike düzeyine sahip ve tahribata uğramayan doğal alanlar ise Kızlar Sivrisi ve Güver Kanyonu olarak göze çarpmaktadır.

Anahtar kelimeler: Turizm ve çevre, doğal alan, çok kriterli karar verme

\section{ABSTRACT}

The existing natural areas need to be protected for the relationship between tourism and the natural environment to be sustainable. The development of tourism activities in a destination with environmental problems is unlikely. This study investigates the environmental danger level in natural areas visited for tourism purposes in Antalya province. In this study, multicriteria decision-making techniques were used to identify the most endangered and vulnerable natural areas. Thus, 15 natural areas are not open for intensive use, and eight criteria are considered to endanger these natural areas. SWARA and MOORA techniques were integrated into the study. After the SWARA determined the weights of the criteria, the hazard levels of the natural areas were listed by the MOORA Method. According to the criteria weights, the most significant ones were "pollution level" and "carrying capacity," while the least effective criterion was "proximity to the water source." Regarding the MOORA rate and MOORA reference method results, the natural areas with the highest possible level of danger are "Korsan Koyu," "Gizli Koy," and "Ceneviz Koyu." On the other hand, the least dangerous and nondestructive natural areas were "Kızlar Sivrisi" and "Güver Kanyonu."

Keywords: Tourism and environment, natural area, multicriteria decision making

Başvuru/Submitted: 07.07.2020 • Revizyon Talebi/Revision Requested: 06.08.2020 • Son Revizyon/Last Revision Received: 14.08 .2020 • Kabul/Accepted: 17.08 .2020 - Online Yayın/Published Online: 02.12.2020

Sorumlu yazar/Corresponding author: Onur SELÇUK / onurselcuk@akdeniz.edu.tr

Atıf/Citation: Selcuk, O., Karakas, H. \& Ipekci Cetin, E. (2020). Antalya ilinde turizme açık doğal alanların tehlike düzeylerinin bütünleşik SWARA-MOORA yöntemi ile belirlenmesi. Cografya Dergisi, 41, 77-91. https://doi.org/10.26650/JGEOG2020-0059 


\section{EXTENDED ABSTRACT}

The existing environment needs to be protected for the relationship between tourism and the natural environment to be sustainable. A quality environment is significant for the competition of touristic destinations. However, the natural area's development is also essential to reveal the environmental impacts based on tourism. In this context, several concepts and activities can be stated, which indicate the danger of tourism activities for natural areas. This study aims to determine the level of danger caused by the tourism activities of the natural areas in Antalya province. Thus, solutions can be proposed for the natural areas that need the most protection. In this study, 15 areas that stand out with their natural attraction in Antalya province: "Adam Kayalar," "Altınbeşik Mağarası," "Ceneviz Koyu," “Cennet Koyu," "Eğrigöl Yaylası," "Gizli Koy," “Güver Kanyonu,” "Kizlar Sivrisi,” “Kocaçay Şelalesi,” “Korsan Koyu,” “Kral Havuzu," "Maden Koyu," "Sapadere Kanyonu," "Tilkiler Mağarası," "Uçansu Şelalesi” are chosen as alternatives. Besides, the carrying capacity of the Natural Area, distance to the city center, the level of pollution assessed by past visitors, distance to the nearest water source, the presence and number of endemic plant species in the region, the number of accommodation in the area, and the number of tours or trips to the region were determined as effective criteria in determining the hazard levels of natural areas.

In this study, SWARA and MOORA techniques, which are among the MCDM techniques, were preferred and applied in an integrated (hybrid) manner. The criterion weights obtained with the SWARA technique are included in an input to the MOORA technique. From the SWARA technique's result, the most effective criteria in indicating the hazard levels of natural areas are "pollution level (0.22)" and "carrying capacity (0.18)." "Being close to the water source" has been identified as the least effective criterion for endangering natural areas. After the criteria weights were finalized, the MOORA technique was implemented. Within the scope of the research, the alternatives with the highest possible level of danger and suffered the most damage are "Korsan Koyu," "Gizli Koy," and "Ceneviz Koyu." On the other side, it is obtained that the natural areas with the lowest level of danger and less destruction than others are the "Kizlar Sivrisi" and "Güver Kanyonu."

In light of the study findings, the hazard factors that may arise from touristic activities in Antalya's natural tourism areas and the current hazard levels are revealed. In this context, it has been concluded that natural areas, especially located in coastal areas, have the highest level of danger. Thus, sustainable tourism planning should be reviewed starting from these areas and the current problems of past studies such as the Southern Antalya Project should be analyzed well. Coastal areas are more open to demand as they have attractive opportunities for tourists. When looking at the world's tourism trends, most tourism destinations are prone to seaside and coastal areas. Therefore, the situation may cause the natural and cultural destruction of the coastal areas, which tourists frequently prefer to gain momentum in the long term. It can be said that Antalya's development as a coastal tourism city had a great impact on this outcome. However, the tourism activities to be carried out regardless of the carrying capacity will cause the natural area to disappear rapidly and decrease the region's tourist attraction. Thus, it is one of the suggestions to limit the number of tours and trips organized to the regions by considering the balancing use and protection. It is recommended to employ certifications such as Green Star and Blue Flag to protect the coasts. The ecological importance of natural tourism areas can be emphasized through promotional activities. Activities to increase awareness levels of agencies and private groups organizing trips and tours to the natural tourism areas can be developed. It is suggested to academicians whose studies can potentially concentrate in these fields to measure the sustainability of the natural tourism areas and their impact on the destinations and determine other possible factors. 


\section{GÍRIŞ}

Özellikle aşırı ve plansız kentleşme sonucu şehirlerde yeşil alanların kaybı ve çevre sorunlarının artması bireyleri rekreasyon ve turizm amaciyla doğal alanları keşfetmeye yönlendirmiştir (Özkan, 2001). Kişilerin bu yöndeki talebi, karar verici mercileri şehirlerin çevresinde bulunan tarihi, doğal veya kültürel değerlere sahip alanları turizm amaçlı kullanmaya teşvik etmiş̧ir. Ancak söz konusu kaynakların bilinçsizce kullanımı bölgenin turizm ekonomisini olumsuz etkilediği gibi geri dönüşü olmayan çevre sorunlarına da yol açabilmektedir. Turizm ve çevre ilişkisinde turizm faaliyetlerinin bir yandan doğayı korumaya yönelik olduğu gibi bir yandan da tahribatına yol açabileceği görülmektedir. $\mathrm{Bu}$ sorun turizm ve çevre ilişkisinde çelişki yaratmaktadır (Demir, 2002).

Bir bölgedeki doğal alanın turizm etkinlikleri açısından kullanılmasının yaratacağı çevresel etkiler yerel yönetimin ve bölge halkının tutumuna göre olumlu veya olumsuz yönde değişebilmektedir. Turizm faaliyetlerinin geliştiği bölgede çevre bilincinin oluşmasıyla doğal kaynağın korunması teşvik edilebilir ve bu anlamda tabiat parkları, milli parklar gibi planlama ve yönetsel faaliyetler hızlandırılabilir (Kozak vd., 2015, s. 140). Bu durum turizmin doğal çevreye olumlu etkisine örnek olarak gösterilebilir. Çevre turizm alanında bir çekicilik kaynağı iken, turizmin en önemli etkileri çevreye olmaktadır. Turizm ve doğal çevre ilişkisinin sürdürülebilir olabilmesi için var olan çevrenin korunması gerektiği ortadadır. Korunan ve kullanma dengesi dikkate alınan doğal alanlar turizm açısından rekabet avantajı yaratabilmektedir. Bu bağlamda bir bölgedeki turistik faaliyetler bir oranda sahip olunan kaynakların çekiciliğine bağlıdır. Söz konusu kaynaklar doğal, tarihi ve kültürel varlıklar olabilmektedir. $\mathrm{Bu}$ anlamda kaynakları tükenmiş bir destinasyonda turizmin gelişmesinin zor olacağından söz edilebilir. Ayrıca doğal alanın turistik açıdan gelişim düzeyi de çevresel etkilerin durumunu ortaya koyması bakımından önem arz etmektedir. Bir destinasyon için genellikle turizmin olumlu ekonomik etkileri ön planda düşünülmekte, bölgede yaratacağ etapta göz ardı edilmektedir. Bu bağlamda turizm faaliyetlerinin ekonomik getirilerinin yanı sıra çevre üzerinde önemli ölçüde etkileri bulunmaktadır. Dolayısıyla turistik bölgelerin rekabeti için kaliteli bir çevre önem arz etmektedir (Inskeep, 1991). Bölgedeki turistik etkinlikler doğal alanları tahrip edebilmekte flora ve faunaya zarar vermekte, çevre kirliliğine yol açmaktadır (Simon vd., 2004). Bu alanların kullanımının kontrol edilmemesi, izlenememesi veya duyarsız kalınması doğal kaynağın değerini olumsuz yönde etkilemektedir. Bu açıklamalar neticesinde bir bölgede turizm faaliyetlerinin gerçekleştĭgi doğal alanların çevresel durumunun ortaya konması ya da tehlike düzeyinin belirlenmesi önem arz etmektedir. Alan yazın incelendiğinde Antalya ilinde yer alan doğal alanların söz konusu durumunu değerlendiren herhangi bir araştırma bulgusuna rastlanmamıştır.

Bu çalışmanın amacı Antalya ilinde yer alan yoğun kullanıma açılmamış doğal alanların turizm faaliyetleri etkisi ile oluşan tehlike düzeyinin belirlenmesidir. Çalışma alanı olarak Antalya yöresinin seçilmesinde ilde var olan doğal çekiciliklerin turizm açısından rağbet görmesi ve kitle turizminin yanı sıra doğa temelli turizm potansiyelinin yüksek olması etkili olmuştur. Bununla birlikte talep gören ve yoğun kullanıma maruz kalmış doğal turizm alanları hakkında yerel haberlerde ve sosyal mecralarda kirlilik düzeyi, insan kalabalığ 1 gibi turizm faaliyetlerinin yol açtığı olumsuz etkiler gözlenmiştir. Bu durum da çalışma alanının seçiminde etkili olmuştur. Bu çalışma ile korunmaya en muhtaç doğal alanların belirlenmesinin yanı sıra doğal alanların yok olmasına etki eden faktörler de ortaya konmaktadır. Çalışmanın ilerleyen kısmında turizmin doğal alanlar üzerindeki etkileri açıklanmış, yöntem kısmında çalışmada kullanılan çok kriterli karar verme tekniklerinden bahsedilmiş ve yapılan analizler sonucunda elde edilen bulgular yorumlanmıştır.

\section{TURİZMIN DOĞAL ALANLARA ETKİSI}

Doğal alanlar için turizm faaliyetlerinin yaratacağı tehlikeyi gösteren bir takım kavram ve etkinliklerden bahsedilebilir. Turizm ve doğal çevre ilişkisi üzerine genel olarak alan yazın incelenmiş ve bu çalışmada taşıma kapasitesi, doğal alana şehir merkezinden ulaşım mesafesi, alandaki kirlilik düzeyi, kullanılabilir su kaynağına yakınlık, bölgedeki endemik canlı türü, civardaki konaklama tesisi sayısı ve bölgeye düzenlenen tur ve gezilerin varlığ 1 doğal alanların tehlike düzeylerinin belirlenmesine etki eden kriterler olarak ele alınmıştır. İlgili kriterlere ait ayrıntılı bilgiler aşağıda başlıklar halinde açıklanmaktadır.

\subsection{Taşıma kapasitesinin doğal alanlara etkisi}

Taşıma kapasitesi (TK) bölgedeki doğal kaynağın, sosyal, kültürel ve ekonomik doğasına zarar vermeden destek verebileceği nüfus miktarıdır. Başka bir tanımla ise taşıma kapasitesi bölgenin bozulmaya başlamadan sağlayabileceği kaynak miktarıdır (Özdemir, 2007, s. 61). Turizm sektörünün temel çekiciliğinin doğal alanları da barındırdığı düşünüldüğünde çevresel kaynakların koruma kullanma dengesi gözetilmesinde 
taşıma kapasitesi kavramı önem kazanmaktadır (Demir ve Çevirgen, 2006). Turizm alanında taşıma kapasitesi destinasyonda fiziksel çevrede ve turist deneyimlerinde fark edilir olumsuz etkiler veya tatminsizliğe neden olmadan taşıyabileceği, karşılayabileceği turist sayısıdır şeklinde de tanımlanabilir (Doğan, 2012; Saarinen, 2006; Simon vd., 2004). Avc1 (2007, s. 490) taşıma kapasitesini bölgedeki kaynaklara negatif etki yapmadan ve ziyaretçi tatminini azaltmadan yerel ekonomi ve kültürüne olumsuz etki oluşturmayan maksimum kullanım olarak tanımlamaktadır.

Taşıma kapasitesi bir bölgede doğal kaynağın çekim gücü ile orayı kullananlar arasında ilişkileri yansıttığından bu ilişkilerin türüne, niteliğine, boyutuna veya yapısal özelliklerine göre taşıma kapasitesi düzeyi farklılık göstermektedir. Bu anlamda taşıma kapasitesinin düzeyini etkileyen önemli faktörler arasında doğal ve kültürel kaynakların değeri, bölgenin ekonomik yapısı, toplumdaki siyasi görüşler ve örgütlenmeler, turistik gelişim düzeyi, yerel halkın ve ziyaretçilerin sosyo-ekonomik ve kültürel özellikleri, rekreasyonel etkinliklerin türleri gibi etkenler sayılabilir (Çavuş, 2002). Alan yazında taşıma kapasitesinin bileşenleri de sıklıkla irdelenmiştir. Saarinen (2006) söz konusu bileşenleri; fiziksel, ekonomik, algısal, sosyal, ekolojik ve politik olarak sinıflandırmaktadır. Simon vd. (2004) ise, sosyal ekonomik ve ekolojik taşıma kapasitesi şeklinde gruplandırmıştır. Avcı (2007), Simon vd. (2004)'ne ek olarak sinıflandırmasına psikolojik taşıma kapasitesini eklemiştir. Sözü edilen TK türleri için örneğin fiziksel taşıma kapasitesi sayısal değerler alabilirken sosyal taşıma kapasitesi sözel niteliktedir. Dünya Turizm Organizasyonu ve UN Çevre Programı (1992), turistik bir bölgede ziyaretçi taşıma kapasitesi için temel bir formül önermiştir (MPA, 2004);

"Taşıma Kapasitesi= Ziyaretçi tarafından kullanılan alan / Kişi başına düşen standart alan”

Doğal alanlarda günübirlik etkinlikler için taşıma kapasitesine yönelik bazı standartlar kullanılmaktadır. Buna göre kapasite değerleri (Gülez, 1989; Sakarya, 2000) bir hektarlık günübirlik kullanım alanı başına genelde 250 kişi olarak hesaplanmıştır. Ancak, doğal kaynakların özelliklerine göre hektar başına düşen kişi sayısının minimum 150 kişi ile maksimum 250 kişi arasında değişebileceği görülmektedir.

Turizme açılacak bir alanda taşıma kapasitesi dikkate alınmadan gelişecek faaliyetler o bölgede olumsuz sonuçlar doğurabilmektedir. Bir destinasyonda taşıma kapasitesinin aşılması alanın doğal yaşamına, bölgedeki yerli halkın yaşantısında kültürel ve ekonomik değişimlere neden olabilmektedir. Bakıldığında turizmin sürdürülebilirlik üzerinde en olumsuz etkisinin doğal çevreye olduğu söylenebilir. Taşıma kapasitesi aşılan bir destinasyonda doğal alanlar, aşırı kullanım sonucu zarar görmekte, kontrolsüz gelişme nedeniyle çeşitli faaliyetler için kaynak yetersizliği yaşanmakta, çevre kirliliği oluşmaktadır. Yeraltı su kaynakları kirlenmekte, canlıların habitatı zarar görmekte, bölgenin topoğrafyası değişebilmektedir. Turizmin yaratacağı bu olumsuzluklar geri dönüşü mümkün olmayan çevresel etkilere neden olabilmektedir.

\subsection{Ulaşım mesafesinin doğal alanlara etkisi}

Doğal alanlarda gerçekleştirilen turizm faaliyetlerinin varlığ bölgedeki altyapı imkanlarını etkileyebilmektedir. Turizm açısından kullanılacak olan doğal alanın yerleşim merkezine uzaklığı yerleşim, haberleşme ve ulaşım açısından güvenliği ve yerel halkın doğal turizm uygulamalarına karşı tutumunu değiştirmektedir (Kiper ve Arslan, 2007). Ulaşım açısından yerleşim merkezine uzak olan doğal alanlarda rekreasyonel amaçlı geziler ve araçlı turlar toprağın üst yapısını sertleştirmekte ve yoğun olarak kullanılan yollardaki bitki kökleri zarar görebilmektedir (Akten ve Gül, 2014). Diğer taraftan yollarda buzlanma için kullanılan tuz, eksoz emisyonları ve lastik atıkları çevrede su, hava ve toprak kirliliği oluşturmaktadır (Eltan vd., 2016).

\subsection{Kirlilik düzeyinin doğal alanlara etkisi}

Turizm sayesinde deniz, kum, güneş, manzara gibi doğal değerlerden döviz geliri sağlanması gelişmekte olan ülkeler için önemli bir firsat olarak görülmektedir. Ancak bu durumun önemli bir sonucu olarak sürdürülebilirliğin sağlanamadığ 1 turistik alanlarda çevre kirliliği en sık tartıșılan konu haline gelmiştir. Çevre kirliliğini; hava, toprak ve suyun biyolojik, kimyasal ya da fiziksel olan özelliklerinde insan faaliyetleriyle meydana gelen ve doğal dengeyi bozan, canlılar ve cansız varlıklar üzerinde olumsuz etkilere sebebiyet veren bir olgu olarak tanımlamak mümkündür (Ertürk, 2009). Olumsuz etkileri yaratan insan faaliyetlerinin en önemlileri arasında yer alan turizmin temeli olan kültürel, doğal, çevresel ve tarihi değerlerin geri dönüşü olmayan zararlara maruz kalmaya başlaması sürdürülebilir turizm faaliyetlerine ihtiyaç olduğunu göstermektedir (Kızılırmak, 2011; Pelit vd., 2015; Cinnioğlu, 2015). Turizm bölgelerinde gerekli önemler alınarak mevcut durumunun korunması mümkün olmazsa çevre üzerinde meydana gelen olumsuzlukların yanında, sosyo-kültürel ve ekonomik açıdan olumsuz sonuçlar da ortaya çıkmaktadır 
(Özmen, 2020). Bir turistik destinasyonda yaşanan çevresel zararların çevredeki diğer destinasyonları da etkilediği ve doğal kaynakların tükenebilir yapıda olduğunun anlaşılması tüm paydaşların çevresel bir sorumluluk bilincinin olması gerektiğini göstermiştir (Seyhan ve Yılmaz, 2010). Pils ve arkadaşlarına (1996) göre doğada yapılan etkinlikler sonucunda doğaya verilen zararlar gürültü kirliliği, su kirliliği, çöplerin uzaklaştırılmasında yaşanan zorluklar, kanalizasyon sorunları, spor alanlarındaki binalardan dolayı görsel kalitenin bozulması, tırmanış için kayaların işaretlenmesi, aşırı kullanıma bağlı olarak patikaların bozulması, taşıt kullanımı sonucu oluşan hava kirliliği, bitki örtüsünün tahribi şeklinde sıralanabilir.

\subsection{Su kaynağına yakın olmanın doğal alanlara etkisi}

Konaklama hizmetinin sunulduğu alanlarda temel ihtiyaç kaynaklarından biri de su kaynağının varlığıdır. Bu alanlarda turizm sektörü çok miktarda su tüketmekte ve bu durum bölgede su kıtlığına, azalmaya ve bölgedeki habitatın değişimine neden olabilmektedir (Avc1, 2007, s. 488). Örneğin 100 odalı bir otel odasında maksimum su akış hızının 15 lt/dk olduğu hesaplandığında yılda otelin sadece bir odasının su tüketimi yaklaşık 8000 m3'tür (Şahin, 2016). Bu oran turizm tesislerinin su kaynaklarını tüketmede büyük paya sahip olduğunu göstermektedir. Bu noktada tesislerin su kaynağı kullanımında sürdürülebilir stratejiler geliştirmesi önem arz etmektedir.

Doğal alanlarda su kaynağının varlığı vahşi hayvanlar için hayati önem taşımaktadır. Dolayısıyla su kaynakları yakınında sıklıkla kamp yapılması ya da günübirlik geziler yapılması vahşi hayvanların yaşam alanını değiştirmesine ya da saldırılara neden olacağı için tehlike yaratabilmektedir (Ergün, 2006). Ayrıca su kaynaklarının çevresinin kirli bırakılması toprak ve su kirliliğine neden olmakta, bu durum mevcut canlı türlerini olumsuz etkilemektedir (Yalçın Özdilek, 2006). İyi planlanmadığında ormanlık alanlarda düzenlenen şenlikler/festivaller toprak ve kaynaklarının kirlenmesine ve tahrip olmasina neden olabilmektedir (Gül ve Atken, 2005). Festival alanında kullanılan geçici tuvaletlerin atık sularının yakın civardaki derelere, toprağa gelişigüzel atılması yine toprak ve su kirliliğine neden olmaktadır (Yüksek, Cengiz ve Yüksek, 2007). Yüksek vd. (2007) Artvin ilinde yer alan Kafkasör Yaylasında düzenlenen festivallerin altyapı yetersizliği ve kullanım planının eksikliği nedeni ile bitki, toprak ve su kaynakları üzerinde büyük bir tehdit oluşturduğunu ortaya koymuşlardır. Diğer taraftan kent merkezine yakın çevrelerde bulunan doğal alanlarda su kaynakları fazlasıyla baskı altında kalmaktadır (Manavoğlu, 2009). Bu anlamda şehir planlamalarında doğal alanlar dönüştürülürken çoğu zaman su kaynaklarına tam anlamı ile müdahale edilememekte, kontrol altına alınamamaktadır. Buradan hareketle doğal bir alanı yapılaşmaya açmamak koruma anlamında önemli bir yaklaşım olacaktır (Sılaydın, 2007). Doğal kaynakların koruma kullanma dengesinin yakalanması, sürdürülebilirliğinin oluşması için kirlilik kaynaklarının yüzey ve yer altı sularına olabildiğince uzak tutulması gereklidir. Doğal alanların aşırı kullanımı, kirletilmesi doğal ekosistem dengesinin bozulmasına neden olmaktadır. Bu durum hava, su ve toprak kirliliği ile doğrudan ilişkilidir (Tomar, 2009).

\subsection{Endemik bitki türü varlığının doğal alanlara etkisi}

Türkiye gibi bitkisel biyoçeşitliliği yüksek nadir ve endemik bitki sayısı fazla olan ülkelerde bu durum doğa turizmi için önemli bir firsat yaratmaktadır (Külekçi ve Bulut, 2016). Ancak kontrolsüz turizm gelişmesi, ekolojik dengeyi bozmaktadır. $\mathrm{Bu}$ nedenle turizm içerisinde biyoçeşitlilik unsuruna dayalı faaliyetlerin sürdürülebilir olması için koruma işlevi önem arz etmektedir. Habitat kaybı ve çevresel kirliliğin yanında turizm faaliyetlerinin bilinçsizce sürdürülmesi doğal alanlardaki bozulmayı ve flora sisteminde tahribatı arttırmaktadır. $\mathrm{Bu}$ durum bir çekicilik unsuru olarak görülen doğal güzelliklerin bir süre sonra ortadan kalkması ve bölgedeki endemik türlerin hızla tahribatı sonucunda bölgenin ekolojik çöküşünün oluşmasına sebep olmaktadır. Simon vd. göre (2004), artan rekreasyon çalışmaları flora ile fauna çeşitliğine zararlar vererek kirliliğe ve erozyona yol açmakta sonuçta doğal kaynaklar üzerine olumsuz etkiler yaratmaktadır. Turizm faaliyetleri içerisinde özellikle korunması gereken doğal alanlarda flora ve faunanın korunmasına özel önem verilen tur rotaları düzenlenmeli, turizm faaliyetleri denetlenebilir nitelikte olmalı ve koruma ilkelerini gözeterek sik sik yeni rotalar oluşturulmalıdır (Tuncer ve Çavuş, 2017). Bir çekicilik unsuru olan endemik türlerin korunması için biyo-kaçakçılığa dikkat edilmesi, endemiklerin doğal popülasyonları üzerinde baskı oluşturulmayacak ve mevcut baskının yok edilmesini sağlayacak önemler alınması doğal alanların turizm faaliyetlerini sürdürebilmesi için zorunludur (Erken vd., 2019).

\subsection{Civardaki konaklama tesisi varlığının doğal alanlara etkisi}

Turizmin çevresel etkilerinde önemli bir yer tutan konaklama işletmelerinin plansız, kontrolsüz büyümesi ve işletilmesi ciddi çevresel sorunlara yol açabilmektedir (Dief ve Font, 2010). Doğal turizm alanlarında konaklama yeme-içme tesislerinin doğaya uygun, daha küçük işletmeler halinde ve ekolojik 
ilkeleri benimseyerek faaliyetlerini sürdürmesi iletişim ve ulaşım araçlarının çevreyi en az kirletecek şekilde geliştirilmesi turizm destinasyonunun gelecekte de çekim alanı olarak görülmesi için önemli bir husustur (Dehoorne ve Tătar, 2013). Doğal alanların turizme açılması bir denetim ve düzenleme ile gerçekleşmediği takdirde yapılaşmalardan kaynaklanan tahribat oranı giderek artacaktır. Bölgede yer alan konaklama işletmelerinin sayısının yüksekliği çevre kirliliğinde artışı tetiklediği için az sayıda ve ekolojik ilkeleri benimsemiş konaklama işletmeleri doğal alanların sürdürülebilirliği için önemlidir. Çevreye duyarlı işletmecilik, işletmelerin tüm faaliyetlerinde çevreyi dikkate alan, çevreye verilen zararı minimuma indiren, çalışanlarını çevre duyarlılığ eğiten, temiz teknolojileri kullanan, ekolojik çevrenin korunması için projeler gerçekleştirmeyi ön planda tutan bir anlayıştır (Sert, 2017). Bu nedenle özellikle doğal turizm destinasyonlarının bulunduğu bölgelerde çevreye duyarlı hizmet anlayışı ile hareket eden ve sınırlı sayıda işletmenin olması sürdürülebilirlik için önemli bir husustur.

\subsection{Bölgeye düzenlenen tur veya gezilerin doğal alanlara etkisi}

Günübirlik turizm faaliyetleri kontrolsüz gerçekleştiği takdirde konaklama faaliyetlerinden daha fazla oranda bölgeyi zarara uğratmaktadır. Plajlara düzenlenen tekne turları ve bu faaliyetler ile birlikte turistler tarafından off-road araç aktivitelerinin kullanılması özellikle koylar üzerinde ciddi hasara yol açmaktadır. Dağlık ve iç bölgelerde ise arazi araçları ile yapılan turistik gezi faaliyetleri fauna, bitki örtüsü ve etrafindaki hassas alanlar üzerinde yıkıcı etkilere sebep olmaktadır (McLachlan vd., 2013; Silva ve Ghilardi-Lopez, 2012). Doğal kaynaklı turizm destinasyonlarında kontrolsüz tur veya geziler ve ziyaretçi sayısının taşıma kapasitesini aşacak düzeyde olmasının bölgenin ekolojik dengesini zarara uğrattığı bilinmektedir. Bu nedenle tur organize eden acentelerin ve tur katılımcılarının uyması gereken kurallar dikkate alınmalıdır (Arat ve Çalıml1, 2019). Düzenlenecek tur güzergâhları, yürüyüş, bisiklet yolları doğanın bir parçası olarak teknolojiden biraz uzak durarak planlaması destinasyonun korunması için önemli adımlardır

\section{VERI VE YÖNTEM}

Çalışmada Çok Kriterli Karar Verme (ÇKKV) yöntemlerinden yararlanılmışır. ÇKKV sosyal bilimler, işletme, ekonomi, üretim, mühendislik, eğitim, turizm gibi birçok disiplinde çeşitli uygulamalara sahiptir. Ele alınan problemde çoklu alternatiflerin yer alması ve alternatiflerle ilişkili kriterlerin ağırlıklarının veya önem derecelerinin birbirinden farklı olması durumunda ÇKKV teknikleri kullanılabilir. ÇKKV teknikleri araştırmacıya mevcut alternatifleri kriter ağırlıklarına göre değerlendirme, sıralama, seçim yapma ve en iyi çözüme ulaşma olanağı sunmaktadır (Genç ve Masca, 2013; Ömürbek vd., 2014). Alan yazında çok sayıda ÇKKV tekniği bulunmaktadır. Bu çalışmada ÇKKV tekniklerinden SWARA ile MOORA tekniği tercih edilmiş ve bütünleşik (hibrit) bir şekilde kullanılmıştır. SWARA yöntemi ile elde edilen kriter ağırlıkları MOORA yöntemine girdi olarak dahil edilmiştir. Çalışmanın genel araştırma süreci Şekil 1'de sunulmaktadır.

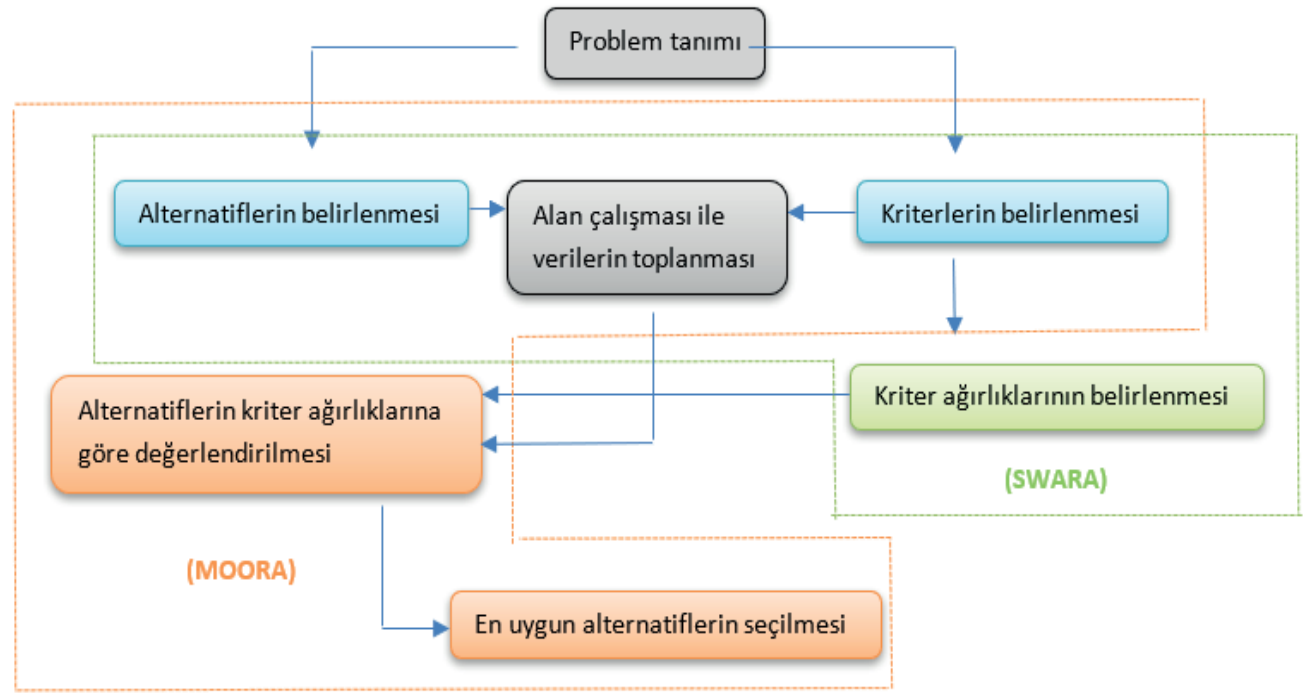

Şekil 1: Araştırma süreci.

Figure 1: Research Process. 


\subsection{SWARA yöntemi}

Alan yazında AHP, Entropi, ANP vb. gibi kriter ağırlıklarını hesaplamada kullanılan ÇKKV teknikleri bulunmaktadır. SWARA tekniği de ağırlık hesaplamada kullanılan tekniklerden biridir. Açılımı "Step-Wise Weight Assessment Ratio Analysis" dır ve Türkçe'de "Adım Adım Ağırlık Değerlendirme Oran Analizi" olarak kullanılmaktadır (Çakır, 2017). Bu teknik ilk olarak Keršuliene, Zavadskas ve Turskis (2010) tarafindan ortaya konulmuştur. Uzmanlarla birlikte çalışmaya oldukça uygun olması ve oldukça kolay uygulanması nedeniyle (Özbek, 2017, s. 43) SWARA diğer tekniklere göre son zamanlarda sıklıkla tercih edilmeye başlanmıştır. Farklı karar vericilerle aynı anda çalışılabilmesi araştırmacıya zamandan ve maliyetten tasarruf yaratabilmektedir. Ayrıca SWARA tekniğinde kriterler arasında yapılan kıyaslama işlemi AHP tekniğine göre daha azdır. Diğer taraftan bu teknikte karar vericiler daha öznel davranabilmektedir (Hashemkhani Zolfani ve Saparauskas, 2013). Uygulama esnasında alternatiflerin değerlendirilmesinde kullanılan kriterler önemliden önemsize doğru siralanmakta ve önemsiz kriterler elenmektedir. Kriterlerin önem ağırlıkları hesaplanırken karar vericilerin oluşturduğu sıralama değerlendirilmektedir (Keršuliene vd., 2010). Sonrasında kriterler birinci sirada yer alan kritere göre beşer puanlık aralıklar kullanılarak önem derecesi belirlenerek azalan seviyede sıralanmaktadır. Sonunda göreceli olarak karar verici sayısı kadar kriterlerin ağırlıklarını açıklayan vektörler elde edilmektedir (Keršulienè ve Turskis, 2011). Son olarak kriterlerin öncelik değerinin geometrik ortalaması alınarak nihai ağırlık değerleri elde edilir (Özbek, 2017). Karar vericiler kriterleri ayrı ayrı değerlendirebileceği gibi bir fikir birliği geliştirerek ortaklaşa da kriterleri değerlendirebilmektedir. SWARA tekniği ile kriter ağırlıklarının belirlenmesi için işlem aşamaları aşağıdaki gibidir.

1. Adım: Kriterler karar vericilerin kişisel değerlendirmeleri ile önemliden önemsize doğru sıralanır.

2. Adım: Karar vericiler ikinci önemli kriterden başlayarak, her bir kriter için göreli önem düzeylerini belirler. Bunun için, “j” kriteri ile bir önceki kriter "j-1" karşılaştırılır. Bu oran "ortalama değerin karşılaştırmalı önemi" olarak adlandırılmıştır ve " $s_{j}$ " simgesi ile gösterilmektedir (Keršuliene vd., 2010).

3. Adım: Tüm kriterler için katsayı değeri " $k_{j}$ ", aşağıda verilen eşitlikten yararlanarak belirlenir. En büyük " $s_{j}$ " değerine sahip kritere ait katsay1 " $k_{j}=1$ " değerini almaktadır (Yurdoğlu ve Kundakc1, 2017). $k_{j}=\left\{\begin{array}{rr}1, & j=1 \\ s_{j}+1, & j>1\end{array}\right.$

4. Adım: Tüm kriterler için 3. Adımdaki hesaplama sonucu yeni bir vektör elde edilir. Aşağıda verilen eşitlik ile önem vektörü " $q_{j}$ ” hesaplanır. Vektör için birinci sıradaki kriterin düzeltilmiş ağırlığı “ $q_{j}=1$ ” dir.

$q_{j}=\left\{\begin{array}{r}1, j=1 \\ \frac{q_{j-1}}{k_{j}}, j>1\end{array}\right.$

5. Adım: Tüm kriterler için göreceli ağırlık değeri “ $w_{j}$ ” aşağıda verilen notasyon ile hesaplanmaktadır. " $w_{j}$ ” simgesi, “j”" kriterin göreceli ağırlığını göstermektedir.

$w_{j}=\frac{q_{j}}{\sum_{k=1}^{n} q_{k}}$

\subsection{MOORA yöntemi}

MOORA (Multi-Objective Optimization By Ratio Analysis) tekniği; ilk olarak Willem Karel M. Brauers ve Edmundas Kazimieras Zavadskas tarafindan 2006 yılında 'Control and Cybernetics' dergisinde yayınladıkları çalışmaları ile tanıtılmıştır (Brauers ve Zavadskas, 2006). Çok kriterli bir karar verme yöntemi olan MOORA, matematiksel işlemlerin sadeliği, hesaplama zamanının kısalığı ve güvenilirliği nedeniyle çalışmalarda sıklıkla tercih edilmektedir. MOORA, bir hedef üzerindeki bir alternatifin, o hedefle ilgili tüm alternatifleri temsil eden bir payda ile karşılaştırıldı̆̆ 1 bir oran sistemi anlamına gelmektedir (Kalibatas ve Turskis, 2008). MOORA tekniğinin alan yazında MOORA Oran metodu, MOORAReferans nokta yaklaşımı, MULTI-MOORA, MOORA-Tam Çarpım Formu ve MOORA-Önem Katsayısı olarak farklı uygulamalarının olduğu görülmektedir (Ersöz ve Atav, 2011; Önay ve Çetin, 2012). Literatürde siklıkla karşılaşılan uygulamaları ise oran metodu ve referans nokta yaklaşımı olurken, her ikisinin bir arada kullanıldığı çalışmalar da bulunmaktadır (Önay, 2018). MOORA tekniğinin personel seçimi (Baležentis vd., 2012; İpekçi Çetin ve İçigen, 2017), bölgesel gelişim değerlendirmesi (Brauers vd., 2010), turistik destinasyonların popülerliğinin değerlendirilmesi (Önay ve Çetin, 2012) gibi farklı karar verme alanlarında kullanıldı̆̆ 1 görülmektedir. Uygulama kolaylığı, hesaplama süresinin kısalığı, içerdiği matematiksel işlemlerin daha az olması ve güvenirlik düzeyi gibi özelliklerine bağlı olarak tercih edilen bu yöntemde, karar seçenekleri ve ölçütler arasındaki tüm 
etkileşimler bütüncül olarak göz önüne alınarak, objektif ağırlıklı değerler ile ağırlıklı normalleştirme yapılır.

\subsubsection{MOORA-Oran metodu}

Oran sisteminde, kriterler temelinde alternatiflerin başlangıç verileri normalize edilir. Oran sistemi yaklaşımı çözümü için ilk olarak $x_{i j}^{*}$ (i alternatif sayısı $\mathrm{j}$ kriter sayısı olmak üzere normalize değerini ifade eden boyutsuz (ölçüleri olmayan) sayı) değerinin hesaplanması gerekmektedir. Kriter temelindeki her bir alternatif, o kriterle ilgili bütün alternatifleri temsil eden bir payda (bölen) ile karşılaştırılır (Kracka vd., 2010). Payda, her kriterin, her bir alternatifte aldığı değerlerin kareler toplamının karekökünü içerir.

$$
x_{i j}^{*}=\frac{x_{i j}}{\sqrt{\sqrt{, \sum_{j=1}^{m} x_{i j}^{2}}}}
$$

Normalleştirme değeri olan $x_{i j}^{*}[0,1]$ arasında değişmektedir. Bazı koşullarda $x_{i j}^{*}[-1,1]$ arasında da değişebilmektedir. Normalleştirme işleminin ardından kriterlerin maksimum veya minimum olma durumlarına göre toplama işlemi gerçekleştirilir ve maksimum kriterlerden minimum kriterler çıkartılarak $y_{i}^{*}(i$ alternatifinin tüm kriterlere göre normalleştirilmiş değerlendirmesi) değeri hesaplanarak işlem tamamlanır.

$$
y_{i}^{*}=\sum_{j=1}^{g} x_{i j}^{*}-\sum_{j=g+1}^{n} x_{i j}^{*}
$$

\subsubsection{MOORA Referans nokta yaklaşımı}

Referans nokta yaklaşımında ise en iyi kriter değeri referans noktası olarak dikkate alınmaktadır (Brauers ve Zavadskas, 2009), referans noktası yaklaşımı daha gerçekçi ve objektif olarak kabul edilmektedir. Referans noktası yaklaşımında, oran sistemi yaklaşımında da kullanılan $x_{i j}^{*}$ formülü ile normalizasyon işlemi yapılmakta ve $x_{i j}^{*}$ formülünden değerler dışarı çıkarılarak "Maksimal Araç Referans Noktası" elde edilmektedir. $x_{i j}^{*}$ değerinin $r_{j}$ değerinden büyük olması durumları göz önüne alınarak mutlak değer içerisinde işlem gerçekleştirilir.

$$
d_{i j}=\left|r_{j}-x_{i j}^{*}\right| \quad P_{i}=\operatorname{Min}_{(i)}\left(\operatorname{Max}\left|r_{j}-x_{i j}^{*}\right|_{(j)}\right)
$$

\subsection{Alternatiflerin belirlenmesi ve veri toplama süreci}

Çalışma kapsamında Antalya ilinde doğal çekicilikleri ile öne çıkan 15 doğal alan alternatifler olarak belirlenmiştir. Alternatiflerin belirlenmesi için Antalya ili içerisinde bulunan doğal turistik alanlara ilişkin genel bir tarama yapılmıştır. Söz konusu değerlendirme gerçekleştirilirken Kültür ve Turizm Bakanlığ turizm portalı, sosyal medyada yer alan gruplar ve

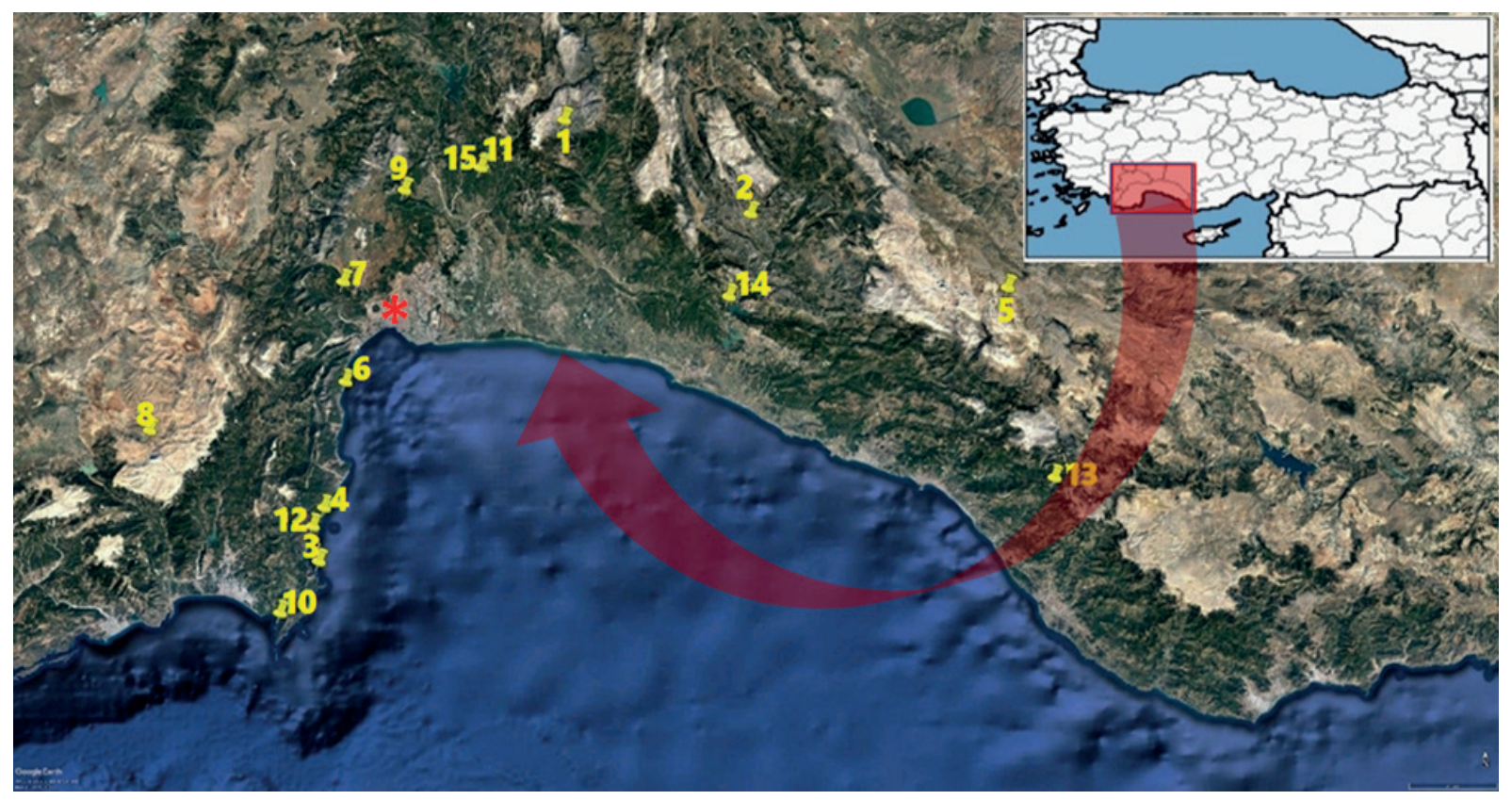

Şekil 2: Çalışmaya Dahil Edilen Doğal Alanlar (Alternatifler).

Figure 2: Natural Areas Included in the Study (Alternatives).

1. Adam Kayalar 2. Altınbeşik Mağarası 3. Ceneviz Koyu 4. Cennet Koyu 5. Eğrigöl Yaylası 6. Gizli Koy 7. Güver Kanyonu 8. Kızlar Sivrisi 9. Kocaçay Şelalesi 10. Korsan Koyu 11. Kral Havuzu 12. Maden Koyu 13. Sapadere Kanyonu 14. Tilkiler Mağarası 15. Uçansu Şelaleleri *Antalya Şehir Merkezi 
çeşitli forumlar incelenmiş̧tir. Doğal alanlar belirlenirken bölgenin turistik destinasyon olarak keşif aşamasında ve henüz doygunluğa ulaşmamış olan yerler tercih edilmiştir. Bölgenin henüz turizm faaliyetlerinden kaynaklanan tahribat düzeyinin düşük olması varsayımının alınabilecek önlemlerin etkinliğini artıracağı düşünülmüştür. Dolayısıyla doğal alanın içerisinde konaklama, park, restoran, kafe, büfe gibi kompleks tesislerin olmamasına ve bu tesislerin belirli bir mesafe ile çevrede bulunuyor olmasına dikkat edilmiştir. Ayrıca belirlenen doğal kaynakların yerli ve yabancı turistler tarafindan ziyaret edilmesi ve tur veya gezilerin düzenleniyor olması da göz önünde bulundurulmuştur. Bu kapsamda araştırma kapsamına on beş doğal turizm alanı dahil edilmiştir. Çalışmaya dahil edilen alanlar ve harita üzerindeki konumları Şekil 2'de görülmektedir.

Çalışma kapsamında ele alınan doğal alanların tehlike düzeylerinin belirlenmesinde etkili olan kriterler alan yazında doğal alanların korunması ve tahribatını en fazla etkileyen etmenlere göre belirlenmiş ve doğal alanları tehlikeye sokması muhtemel 8 kriter ele alınmıştır. Önceki kısımlarda ayrıntılı olarak yer verilen doğal alanın taşıma kapasitesi, şehir merkezine uzaklığı, geçmiş ziyaretçiler tarafından değerlendirilen kirlilik
Ulaşım mesafesi ile ilgili veriler doğal alanların coğrafi konumunun Şekil 2'de gösterilen Antalya şehir merkezine kara yolu üzerinden mesafesi baz alınarak hesaplanmıştır. Bölgedeki konaklama tesisi sayısı hesaplanırken beş kilometre çevresinde var olan turizm konaklama tesisleri internette online haritalar üzerinden saptanmıştır. Kirlilik düzeyi kriteri için belirlenen alternatiflere ilişkin online platformlarda geçmiş ziyaretçilerin kirlilikle ilgili yorumları ayrıntılı olarak incelenmiştir. İlgili yorumlarda metinlerdeki kirlilik değerlendirmeleri temel alınarak araştırmacılar tarafından bir karar ölçütü oluşturulmuştur. Bu karar ölçütü bağlamında kirlilik düzeyi ile ilgili olarak kirli değil (1), az kirli (2), kirli (3) ve çok kirli (4) şekilde puanlama yapılmıştır. Puanlama yapılırken her bir doğal alanla ilgili kirli veya temiz olma durumuna ilişkin yapılan yorumlar değerlendirilmiş ve genel eğilime göre puanlanmıştır. Su kaynağına yakınlık kriteri için belirlenen alternatiflere bölgedeki en yakın içme suyuna ulaşabilecek kaynak ile aradaki mesafe referans alınmıştır. Bölgedeki endemik bitki türü sayısını belirmek için Kültür ve Turizm Bakanlığı, Antalya il çevre raporları ve Antalya'da yer alan milli parklar ve tabiat parklarının online arşivleri taranmıştır. Son olarak bölgeye düzenlenen geziler veya turların sayısının belirlenmesinde bölgede faaliyet gösteren seyahat acentelerinin hizmet arşivleri incelenerek 2019

Tablo 1: Doğal Alanları Tehlikeye Atabilecek Durumlar (Kriterler).

Table 1: Conditions That Can Endanger Natural Areas (Criterions).

\begin{tabular}{|c|c|c|}
\hline Sıra Numarası & Kriter & Tanım \\
\hline$\overline{\mathrm{K} 1}$ & Taşıma Kapasitesi & Turistik bölgenin bozulmaya başlamadan hizmet verebileceği kişi sayısı (Hektar*150 kişi) \\
\hline $\mathrm{K} 2$ & Ulaşım Mesafesi & Doğal alanın, şehir merkezine olan kara yolu mesafesi (km) \\
\hline K3 & Kirlilik Düzeyi & $\begin{array}{l}\text { Doğal alanda beşerî faaliyetler sonucu oluşan toprak, su, hava, gürültü kirliliğinin genel düzeyi (kirli değil } \\
\text { (1), az kirli (2), kirli (3) ve çok kirli (4)) }\end{array}$ \\
\hline K4 & Su Kaynağına Yakınlık & Doğal alanın kullanılabilecek içme suyuna uzaklığı (m) \\
\hline K5 & Endemik Bitki Türü & Doğal alanın çevresindeki endemik bitki türü sayısı (adet) \\
\hline K6 & Konaklama Tesisi Sayısı & Doğal alanın 5 km çevresindeki konaklama tesisi sayısı (adet) \\
\hline K7 & Tur veya Gezi Sayısı & Doğal alana bir yıl içerisinde düzenlenen tur veya gezi sayısı (adet) \\
\hline
\end{tabular}

düzeyi, en yakın su kaynağına mesafesi, bölgedeki endemik bitki türü varlığı ve sayısı, beş kilometre çapında yer alan konaklama tesisi sayısı ve bölgeye düzenlenen tur veya gezi sayısı doğal alanların tehlike düzeylerinin belirlenmesinde etkili kriterler olarak belirlenmiştir (Tablo 1).

Çalışmanın veri toplama aşamasında belirlenen kriterlere ilişkin farklı kaynaklar kullanılmıştır. Doğal alanların taşıma kapasitesi hesaplamasında Gülez (1989) ve Sakarya'nın (2000) sunduğu yaklaşım benimsenmiştir. Buna göre doğal alanlarda her bir hektarkare alan için maksimum 150 kişi olacak şekilde seçilen alanların taşıma kapasitesi hesaplanmıştır. Doğal alanların $\mathrm{m}^{2}$ cinsinden büyüklükleri Tablo 2'de görülmektedir.
Tablo 2: Alternatiflerin alan büyüklüğü. Table 2: Area size of alternatives.

\begin{tabular}{lc}
\hline Alternatifler & Alan büyüklüğüu $\left(\mathbf{m}^{\mathbf{2}}\right)$ \\
\hline Adam Kayalar & 100800 \\
Altınbeşik Mağarası & 115600 \\
Ceneviz Koyu & 33860 \\
Cennet Koyu & 19525 \\
Eğrigöl Yaylası & 365333 \\
Gizli Koy & 2200 \\
Güver Kanyonu & 619542 \\
Kızlar Sivrisi & 6100 \\
Kocaçay Şelalesi & 1230 \\
Korsan Koyu & 2350 \\
Kral Havuzu & 450 \\
Maden Koyu & 75000 \\
Sapadere Kanyonu & 11882 \\
Tilkiler Mağarası & 13630 \\
Uçansu Şelaleleri & 76851 \\
\hline
\end{tabular}


yılına dair genel tur ve gezi sayıları hesaplanmıştır. Bunun yanı sıra doğa temelli aktiviteler gerçekleştiren toplulukların web siteleri ve sosyal medya hesapları üzerinden paylaştıkları turlar genel sayıya dahil edilmiştir. Çalışmada yer verilen alternatifler ve kriterlerle ilgili toplanan ham veriler Tablo 3 'te sunulmaktadır.

Tablo 3: Karar Matrisi.

Table 3: Decision Matrix.

\begin{tabular}{lccccccc}
\hline & K1 & K2 & K3 & K4 & K5 & K6 & K7 \\
\hline Adam Kayalar & 1512 & 123 & 1 & 500 & 12 & 1 & 6 \\
Altınbeşik Mağarası & 1725 & 131 & 1 & 200 & 69 & 3 & 112 \\
Ceneviz Koyu & 508 & 85 & 2 & 50 & 45 & 1 & 1560 \\
Cennet Koyu & 288 & 64 & 1 & 50 & 13 & 3 & 200 \\
Eğrigöl Yaylası & 5480 & 181 & 1 & 1700 & 97 & 0 & 19 \\
Gizli Koy & 33 & 28 & 4 & 900 & 21 & 8 & 360 \\
Güver Kanyonu & 9293 & 22 & 3 & 500 & 41 & 1 & 21 \\
Kızlar Sivrisi & 92 & 161 & 1 & 5000 & 17 & 0 & 28 \\
Kocaçay Şelalesi & 18 & 40 & 2 & 750 & 12 & 0 & 9 \\
Korsan Koyu & 35 & 120 & 3 & 20 & 45 & 3 & 1920 \\
Kral Havuzu & 7 & 65 & 1 & 1500 & 17 & 0 & 87 \\
Maden Koyu & 1125 & 73 & 2 & 50 & 13 & 0 & 200 \\
Sapadere Kanyonu & 177 & 175 & 2 & 50 & 15 & 1 & 196 \\
Tilkiler Mağarası & 204 & 98 & 1 & 4000 & 23 & 0 & 2 \\
Uçansu Şelaleleri & 1152 & 63 & 3 & 1200 & 11 & 0 & 340 \\
\hline
\end{tabular}

Çalışmanın amacına uygun olarak veriler toplandıktan sonra analiz sürecine geçilmiştir. Bu bağlamda öncelikle SWARA tekniği ile kriterlerin önem ağırlıkları belirlenmiştir. Daha sonra elde edilen ağırlık değerleri MOORA tekniği işlemleri içerisinde kullanılarak alternatiflerin sıralaması sonuçlandırılmıştır.

\section{BULGULAR}

Çalışmada kullanılacak alternatifler ve kriterler belirlenerek karar matrisi oluşturulduktan sonra Antalya ilinde bulunan ve turistik amaçlı kullanılan doğal alanların maruz kaldığı tehlike düzeyini belirlemek için SWARA ve MOORA teknikleri kullanılmıştır. Öncelikle tehlike düzeyini ortaya koymak için kullanılan kriterlerin önem dereceleri SWARA tekniği ile belirlenmiştir. Değerlendirme üç karar verici tarafından ortak kararlar alarak yapılmıştır. İlgili değerlendirme yöntem kısmında açıklanan SWARA tekniğinin uygulama aşamaları izlenerek gerçekleştirilmiştir. Elde edilen sonuçlar Tablo 4'te sunulmaktadır.

Tablo 4: SWARA tekniği ile kriter ağırlıklarının belirlenmesi. Table 4: Determination of criterion weights with SWARA technique.

\begin{tabular}{llllll}
\hline Sıralama & Kriterler & $\mathbf{s}_{\mathbf{j}}$ & $\boldsymbol{k}_{\boldsymbol{j}}$ & $\boldsymbol{q}_{\boldsymbol{j}}$ & $\boldsymbol{w}_{\boldsymbol{j}}$ \\
\hline $\mathbf{1}$ & $\mathbf{K 3}$ & & 1 & 1 & $\mathbf{0 , 2 2}$ \\
$\mathbf{2}$ & $\mathbf{K} \mathbf{1}$ & 0,2 & 1,2 & 0,833333 & $\mathbf{0 , 1 8}$ \\
$\mathbf{3}$ & $\mathbf{K 5}$ & 0,3 & 1,3 & 0,641026 & $\mathbf{0 , 1 4}$ \\
$\mathbf{4}$ & $\mathbf{K 2}$ & 0,05 & 1,05 & 0,610501 & $\mathbf{0 , 1 3}$ \\
$\mathbf{5}$ & $\mathbf{K 7}$ & 0,1 & 1,1 & 0,555001 & $\mathbf{0 , 1 2}$ \\
$\mathbf{6}$ & $\mathbf{K 6}$ & 0,3 & 1,3 & 0,426924 & $\mathbf{0 , 0 9}$ \\
$\mathbf{7}$ & $\mathbf{K 4}$ & 0,25 & 1,25 & 0,341539 & $\mathbf{0 , 0 8}$ \\
\hline
\end{tabular}

Tablo 4 incelendiğinde en önemli kriterlerin "kirlilik düzeyi $(0,22)$ " ve "taşıma kapasitesi $(0,18)$ " olduğu görülmektedir. Su kaynağına yakın olmak ise doğal alanları tehlikeye sokacak en az etkili kriter olarak belirlenmiştir. Kriter ağırlıkları belirlendikten sonra MOORA tekniğinin uygulama aşamalarına geçilmiştir. Tablo 3'de sunulan ham verilere normalleştirme işlemi uygulanarak, normalleştirilmiş karar matrisi Tablo 5'da gösterilmiştir.

Tablo 5: Normalleştirilmiş karar matrisi.

Table 5: Normalized decision matrix.

\begin{tabular}{lccccccc}
\hline & K1 & K2 & K3 & K4 & K5 & K6 & K7 \\
\hline Adam Kayalar & 0,135 & 0,295 & 0,123 & 0,071 & 0,080 & 0,103 & 0,002 \\
Altınbeşik Mağarası & 0,154 & 0,315 & 0,123 & 0,028 & 0,461 & 0,308 & 0,044 \\
Ceneviz Koyu & 0,045 & 0,204 & 0,246 & 0,007 & 0,301 & 0,103 & 0,612 \\
Cennet Koyu & 0,026 & 0,154 & 0,123 & 0,007 & 0,087 & 0,308 & 0,078 \\
Eğrigöl Yaylası & 0,491 & 0,435 & 0,123 & 0,242 & 0,648 & 0,000 & 0,007 \\
Gizli Koy & 0,003 & 0,067 & 0,492 & 0,128 & 0,140 & 0,821 & 0,141 \\
Güver Kanyonu & 0,832 & 0,053 & 0,369 & 0,071 & 0,274 & 0,103 & 0,008 \\
Kızlar Sivrisi & 0,008 & 0,387 & 0,123 & 0,711 & 0,114 & 0,000 & 0,011 \\
Kocaçay Şelalesi & 0,002 & 0,096 & 0,246 & 0,107 & 0,080 & 0,000 & 0,004 \\
Korsan Koyu & 0,003 & 0,288 & 0,369 & 0,003 & 0,301 & 0,308 & 0,753 \\
Kral Havuzu & 0,001 & 0,156 & 0,123 & 0,213 & 0,114 & 0,000 & 0,034 \\
Maden Koyu & 0,101 & 0,175 & 0,246 & 0,007 & 0,087 & 0,000 & 0,078 \\
Sapadere Kanyonu & 0,016 & 0,420 & 0,246 & 0,007 & 0,100 & 0,103 & 0,077 \\
Tilkiler Mağarası & 0,018 & 0,235 & 0,123 & 0,569 & 0,154 & 0,000 & 0,001 \\
Uçansu Şelaleleri & 0,103 & 0,151 & 0,369 & 0,171 & 0,073 & 0,000 & 0,133 \\
\hline
\end{tabular}

Normalleştirilmiş matris üzerinden SWARA tekniği sonucu elde edilen ağırlık değerleri dikkate alınarak ağırlıklandırılmış normalize matris hesaplanmıştır (Tablo 6). Ağılıklandırma işleminde normalize edilmiş matristeki her bir birim kriterin önem derecesi ile çarpılmıştır. Elde edilen ağırlıklı matris kullanılarak MOORA-Oran metodu yaklaşımını işlemleri gerçekleştirilmiştir. Oran metodunda $\mathrm{Y}^{*}$ değerleri hesaplanırken her bir alternatif için kriterlerin maksimum değerlerinin toplamı minimum değerlerden çıkarılmıştır. Böylelikle her bir alternatif için $\mathrm{Y}^{*}$ değeri bulunmuş ve sıralama yapılmıştır.

Ağırlıklandırılmış matris üzerinden yapılan bir diğer işlem ise MOORA- Referans nokta yaklaşımı hesaplaması olmuştur. Burada öncelikle alternatiflere göre her bir kriter için minimum ve maksimum değerler belirlenerek referans noktaları oluşturulmuştur. Bu noktalar baz alınarak yapılan hesaplamalar sonucu oluşan sıralama Tablo 7'de görülmektedir.

Elde edilen sonuçlara bakıldığında oran metodu ve referans nokta yaklaşımı sıralamalarının genel olarak farklı olduğu görülmektedir (Tablo 8). Tablo 8' de yer alan iki ayrı sıralamada Oran Metodu ile yapılan siralamada ilk sirada Korsan Koyu, ikinci sırada Gizli Koy ve üçüncü sırada Ceneviz Koyu'nun yer 
Tablo 6: Ağırlıklandırılmış karar matrisi ve MOORA- Oran Metodu sonuçlarına göre sıralama. Table 6: Sorting by weighted decision matrix and MOORA-Rate Method results.

\begin{tabular}{|c|c|c|c|c|c|c|c|c|c|}
\hline & Min & Min & Max & Min & Max & Max & Max & \multirow{2}{*}{$\mathbf{Y}^{*}$} & \multirow{2}{*}{ Siralama } \\
\hline & K1 & K2 & K3 & K4 & K5 & K6 & K7 & & \\
\hline Adam Kayalar & 0,0248 & 0,0397 & 0,0271 & 0,0053 & 0,0113 & 0,0096 & 0,0003 & $-0,0216$ & 11 \\
\hline Altınbeşik Mağarası & 0,0283 & 0,0423 & 0,0271 & 0,0021 & 0,0650 & 0,0289 & 0,0054 & 0,0537 & 5 \\
\hline Ceneviz Koyu & 0,0083 & 0,0274 & 0,0542 & 0,0005 & 0,0424 & 0,0096 & 0,0747 & 0,1447 & 3 \\
\hline Cennet Koyu & 0,0047 & 0,0207 & 0,0271 & 0,0005 & 0,0123 & 0,0289 & 0,0096 & 0,0519 & 6 \\
\hline Eğrigöl Yaylası & 0,0900 & 0,0584 & 0,0271 & 0,0182 & 0,0914 & 0,0000 & 0,0009 & $-0,0472$ & 14 \\
\hline Gizli Koy & 0,0005 & 0,0090 & 0,1084 & 0,0096 & 0,0198 & 0,0771 & 0,0172 & 0,2034 & 2 \\
\hline Güver Kanyonu & 0,1527 & 0,0071 & 0,0813 & 0,0053 & 0,0386 & 0,0096 & 0,0010 & $-0,0346$ & 13 \\
\hline Kızlar Sivrisi & 0,0015 & 0,0520 & 0,0271 & 0,0534 & 0,0160 & 0,0000 & 0,0013 & $-0,0625$ & 15 \\
\hline Kocaçay Şelalesi & 0,0003 & 0,0129 & 0,0542 & 0,0080 & 0,0113 & 0,0000 & 0,0004 & 0,0447 & 7 \\
\hline Korsan Koyu & 0,0006 & 0,0387 & 0,0813 & 0,0002 & 0,0424 & 0,0289 & 0,0920 & 0,2051 & 1 \\
\hline Kral Havuzu & 0,0001 & 0,0210 & 0,0271 & 0,0160 & 0,0160 & 0,0000 & 0,0042 & 0,0102 & 10 \\
\hline Maden Koyu & 0,0185 & 0,0236 & 0,0542 & 0,0005 & 0,0123 & 0,0000 & 0,0096 & 0,0334 & 8 \\
\hline Sapadere Kanyonu & 0,0029 & 0,0565 & 0,0542 & 0,0005 & 0,0141 & 0,0096 & 0,0094 & 0,0274 & 9 \\
\hline Tilkiler Mağarası & 0,0034 & 0,0316 & 0,0271 & 0,0427 & 0,0217 & 0,0000 & 0,0001 & $-0,0289$ & 12 \\
\hline Uçansu Şelaleleri & 0,0189 & 0,0203 & 0,0813 & 0,0128 & 0,0104 & 0,0000 & 0,0163 & 0,0559 & 4 \\
\hline Ağırlık değerleri & 0,18 & 0,13 & 0,22 & 0,08 & 0,14 & 0,09 & 0,12 & & \\
\hline
\end{tabular}

Tablo 7: MOORA- Referans noktası yaklaşımına göre sıralama.

Table 7: Sorting according to MOORA-Reference point approach.

\begin{tabular}{|c|c|c|c|c|c|c|c|c|c|}
\hline & Min & Min & Max & Min & Max & Max & Max & Maksimum & Suralama \\
\hline & K1 & $\mathrm{K} 2$ & K3 & K4 & K5 & K6 & K7 & değer & siralama \\
\hline Adam Kayalar & 0,0247 & 0,0326 & 0,0813 & 0,0051 & 0,0801 & 0,0675 & 0,0917 & 0,0917 & 12 \\
\hline Altınbeşik Mağarası & 0,0282 & 0,0352 & 0,0813 & 0,0019 & 0,0264 & 0,0482 & 0,0866 & 0,0866 & 7 \\
\hline Ceneviz Koyu & 0,0082 & 0,0203 & 0,0542 & 0,0003 & 0,0490 & 0,0675 & 0,0172 & 0,0675 & 2 \\
\hline Cennet Koyu & 0,0046 & 0,0136 & 0,0813 & 0,0003 & 0,0792 & 0,0482 & 0,0824 & 0,0824 & 5 \\
\hline Eğrigöl Yaylası & 0,0899 & 0,0513 & 0,0813 & 0,0180 & 0,0000 & 0,0771 & 0,0911 & 0,0911 & 10 \\
\hline Gizli Koy & 0,0004 & 0,0019 & 0,0000 & 0,0094 & 0,0716 & 0,0000 & 0,0747 & 0,0747 & 3 \\
\hline Güver Kanyonu & 0,1526 & 0,0000 & 0,0271 & 0,0051 & 0,0528 & 0,0675 & 0,0910 & 0,1526 & 14 \\
\hline Kızlar Sivrisi & 0,0014 & 0,0449 & 0,0813 & 0,0532 & 0,0754 & 0,0771 & 0,0906 & 0,0906 & 9 \\
\hline Kocaçay Şelalesi & 0,0002 & 0,0058 & 0,0542 & 0,0078 & 0,0801 & 0,0771 & 0,0916 & 0,0916 & 11 \\
\hline Korsan Koyu & 0,0005 & 0,0316 & 0,0271 & 0,0000 & 0,0490 & 0,0482 & 0,0000 & 0,0490 & 1 \\
\hline Kral Havuzu & 0,0000 & 0,0139 & 0,0813 & 0,0158 & 0,0754 & 0,0771 & 0,0878 & 0,0878 & 8 \\
\hline Maden Koyu & 0,0184 & 0,0165 & 0,0542 & 0,0003 & 0,0792 & 0,0771 & 0,0824 & 0,0824 & 5 \\
\hline Sapadere Kanyonu & 0,0028 & 0,0494 & 0,0542 & 0,0003 & 0,0773 & 0,0675 & 0,0826 & 0,0826 & 6 \\
\hline Tilkiler Mağarası & 0,0032 & 0,0245 & 0,0813 & 0,0425 & 0,0697 & 0,0771 & 0,0919 & 0,0919 & 13 \\
\hline Uçansu Şelaleleri & 0,0188 & 0,0132 & 0,0271 & 0,0126 & 0,0811 & 0,0771 & 0,0757 & 0,0811 & 4 \\
\hline Referans Noktaları & 0,00012 & 0,00710 & 0,10840 & 0,00021 & 0,09143 & 0,07715 & 0,09198 & & \\
\hline
\end{tabular}

aldığ1 görülmektedir. Bununla birlikte Referans Nokta Yaklaşımı'na göre birinci sırada Korsan Koyu, ikinci sırada Ceneviz Koyu, üçüncü sırada ise Gizli Koy yer almaktadır. Görüldüğü üzere her iki sıralamada ikinci ve üçüncünün yeri değişse de ilk üç sıralama sonucunun benzer olduğundan bahsedilebilir. Başka bir ifade ile bulgulara göre araştırma kapsamındaki doğal kaynaklardan en fazla tahribata uğrayan, olası tehlike düzeyi en yüksek olan yerler Korsan Koyu, Gizli Koy ve Ceneviz Koyu'dur. Diğer taraftan sonuçların tersi düşünülecek olursa, bulgular incelendiğinde tehlike düzeyi en düşük, diğerlerine göre daha az tahrip edilen doğal kaynaklar Oran Metoduna göre Kızlar Sivrisi, Referans Nokta Yaklaşımına göre ise Güver Kanyonu'dur.
Tablo 8: MOORA tekniği sonuçları.

Table 8: MOORA technique results.

\begin{tabular}{lcc}
\hline & $\begin{array}{c}\text { Oran Metodu } \\
\text { Sıralaması }\end{array}$ & $\begin{array}{c}\text { Referans Nokta } \\
\text { Yaklaşım Sıralaması }\end{array}$ \\
\hline Adam Kayalar & 11 & 12 \\
Altınbeşik Mağarası & 5 & 7 \\
Ceneviz Koyu & $\mathbf{3}$ & $\mathbf{2}$ \\
Cennet Koyu & 6 & 5 \\
Eğrigöl Yaylası & 14 & 10 \\
Gizli Koy & $\mathbf{2}$ & $\mathbf{3}$ \\
Güver Kanyonu & 13 & 14 \\
Kızlar Sivrisi & 15 & 9 \\
Kocaçay Şelalesi & 7 & 11 \\
Korsan Koyu & $\mathbf{1}$ & $\mathbf{1}$ \\
Kral Havuzu & 10 & 8 \\
Maden Koyu & 8 & 5 \\
Sapadere Kanyonu & 9 & 6 \\
Tilkiler Mağarası & 12 & 13 \\
Uçansu Şelaleleri & 4 & 4 \\
\hline
\end{tabular}




\section{SONUÇ VE DEĞERLENDİRME}

Turizmin çok yönlü ve aktörlü bir endüstri olması dolayısıyla bir bölgede turizm faaliyetlerinin gelişimi beraberinde birçok alanı da etkilemektedir. Bu etkileşimde aktörlerin (karar vericiler ve uygulayıcılar) önceliği turizmin ekonomik faydaları üzerindedir. Ancak sosyo-kültürel ve çevresel etkilerinin göz ardı edilmesi destinasyonun sürdürülebilirliğini uzun vadede olumsuz etkileyebilmektedir. Özellikle çevre destinasyon için bir çekicilik kaynağı iken, turizmin en önemli etkileri de bu alanda ortaya çıkmaktadır. Destinasyonun çekici unsurlarını doğal alanlar oluşturuyorsa bu bölgede turizmin sürdürülebilir olması için öncelikle doğal çevrenin korunması gerekmektedir. Bu bağlamda bu çalışmada Antalya ilinde bulunan ve turizm açısından gelişme aşamasında olan doğal alanlarda turizm faaliyetlerinin yarattığ tehlike düzeyinin belirlenmesi amaçlanmıştır. $\mathrm{Bu}$ amaçla belirlenen on beş doğal alan, taşıma kapasitesi, şehir merkezine uzaklığı, kirlilik düzeyi, en yakın su kaynağına mesafesi, bölgedeki endemik bitki türü varllğg ve sayısı, civardaki konaklama tesisi sayısı ve tur veya gezi sayıları kriterleri üzerinden tehlike düzeylerini ortaya koymak üzere ÇKKV teknikleri kullanılarak değerlendirilmiştir. Çalışmanın sonuçlarına göre tehlike düzeyi en fazla olan doğal alanlar kıyı kesimlerinde yer alan koylar olarak bulunmuştur. Dünyada turizm trendlerine bakıldığında turizm faaliyetlerinin çoğunluğu deniz kenarı ve kıy1 kesimlerinde gerçekleşmektedir. $\mathrm{Bu}$ durum turistler tarafından sıklıkla tercih edilen kıyı kesimlerinin doğal ve kültürel tahribatının hız kazanmasına neden olmaktadır. Antalya'nın bir kıyı turizm kenti olarak gelişiminin bu sonuç üzerinde büyük etkisi olduğu söylenebilir. Nitekim son kırk yılda bölgede turizm sektörünün yarattığı ekonomik gelişmeler, işgücüne katılımda büyük oranda artışa neden olmuştur. Bu konuya paralel olarak her geçen yıl artış gösteren bölgedeki turist sayısı birçok destinasyonun taşıma kapasitesini zorlamaktadır. Bu durumun da söz konusu doğal alanları tehlikeye attığı söylenebilir.

Tehlike altındaki koyların konumuna bakıldığında Güney Antalya bölgesinde toplandığı görülmektedir. Bölgenin turizm açısından tarihsel geçmişi incelendiğinde Güney Antalya Turizm Gelişim Projesinin etkileri açıkça görülmektedir. 1970'lerde başlayan, teşvikler ve yatırımlarla hız kazanan bu projenin amacı güneybatı kıyılarında $80 \mathrm{~km}$ uzunluğu kapsayan bir alanda kitle turizmini geliştirmektir. Başlangıçta proje kapsamında orman ve tarım alanlarının korunmasına önem verilirken, sonraki yıllarda yapılan değişiklikler sonucunda doğal kaynakların korunması göz ardı edilerek düzensiz turizm yapılaşması yoğunluk kazanmıştır. $\mathrm{Bu}$ durumun gelişmesi sonucu Güney Antalya bölgesinde yer alan Olympos Beydağları Milli Parkı ve çevresindeki doğal alanlar tahrip edilerek, turizm yapılanması amacıyla kullanılmıştır. Dolayısıyla doğal alanlardaki bu değişim ekolojik dengede bozulmaya neden olmuş, ayrıca orman alanlarının yerel halkın kullanımında olan tarım arazilerinin turizm yapılanmasına devredilmesine sebep olmuștur. Kitle turizminin etkisi altındaki Güney Antalya Bölgesinde turizm ve rekreasyon faaliyetleri için yapılan bu dönüşüm bölgenin bitki örtüsünü, zengin doğal yapısını, yaban hayatını ve bölgede yer alan endemik türlerin korunmasının önemimi gündeme getirmiştir. Kıyı kesimlerinde gerçekleşen bu sorunlara bağlı olarak duyarlı ekosistemlerin var olduğu bu alanların aşırı kullanımı çevresel olumsuz sonuçlar yaratmıştır. Antalya ilinin kıyılarında yaşanan bu sorunlar yalnızca Güney Antalya Bölgesine özgü olmayıp kentin diğer kıyı kesimlerinde de yaşanmıştır. Örneğin Belek bölgesinde özellikle golf ve turizm tesisleri inşası ile ormanlık alanlar tahrip edilmiş, kent merkezinde ise Boğaçay ve Konyaaltı kıyılarının turistik amaçlı kullanımı erozyona sebep olmuştur.

Çalışmada bir diğer bulgusu da ise en az tehlike düzeyine sahip ve tahribata uğramayan doğal alanlar Kızlar Sivrisi ve Güver kanyonu olarak göze çarpmaktadır. Bölgede yapılan trekking ve kaya tırmanışı gibi macera turizmi aktivitelerinin niş pazara hitap etmesi, dolayısı ile bölgeye talebi etkilemektedir. Bu alanlar incelendiğinde nispeten şehir merkezine yakın olmasına rağmen turistik faaliyetleri artıracak yapılanmanın ve turizm planlamasının oldukça az olduğu görülmektedir. Bu sebeplerin söz konusu alanların bakir kalmasına yol açtığı düşünülmektedir. Çalışmada elde edilen önemli bir bulgu da SWARA tekniği sonucunda değerlendirmede kullanılan en önemli kriterlerin "kirlilik düzeyi $(0,22)$ " ve "taşıma kapasitesi $(0,18)$ " olduğunun saptanmasıdır. Alan yazın incelendiğinde de bilimsel çalışmaların bu konular üzerinde önemle durduğu görülmektedir. Su kaynağına yakın olmak ise doğal alanları tehlikeye sokacak en az etkili kriter olarak belirlenmiştir. Çalışmadan elde edilen bulgular ışığında Antalya bölgesindeki turizme açı doğal alanlarda turistik faaliyetler sonucu ortaya çıkabilecek tehlike unsurları ve bu alanların mevcut tehlike düzeyleri ortaya konulmuştur. Sürdürülebilir turizm planlamasının bu alanlardan başlayarak yeniden gözden geçirilmesi ve Güney Antalya projesi gibi geçmiş çalışmaların mevcut sorunlarının iyi analiz edilmesi gerekmektedir. Kıyı bölgeleri turistler için cezbedici imkanları barındırması yönüyle talebe daha açıktır. Ancak taşıma kapasitesi gözetilmeden gerçekleştirilecek turizm faaliyetleri doğal alanın hızla kaybolmasına ve bölgenin turistik çekiciliğinin de azalmasına sebep olacaktır. Bu nedenle uygulayıcılar için koruma kullanma dengesi gözetilerek bölgelere düzenlenen tur ve gezi sayılarına sınırlama getirilmesi önerilerden biridir. Kıyıların 
korunması amacıyla yeşil yıldız ve mavi bayrak gibi sertifikasyonların uygulanması önerilmektedir. Bunun yanında yalnızca tek bir bölge özelinde değil genel anlamda doğal alanları içinde barındıran turizm faaliyetlerinde hem ziyaretçiler hem uygulayıcıların ekolojik bilince sahip olması önem arz etmektedir. Bu nedenle, tanıtım faaliyetleri, tabelalar, afişler, broşürler ve il turizm örgütlerinin web siteleri üzerinden gerçekleştirilerek bölgelerin ekolojik önemine vurgu yapılabilir. Bölgeye gezi ve tur düzenleyen acenteler ve özel grupların farkındalık düzeylerinin arttırılmasına yönelik çalışmalar geliştirilebilir. Belirlenen doğal turizm destinasyonlarının sürdürülebilirliğinin ölçümü ve destinasyon üzerinde etkisi, olabilecek diğer unsurların tespiti için akademik çalışmaların bu alanlarda yoğunlaşması önerilmektedir.

Çalışmada kullanılan doğal alana yakın olan konaklama tesisi sayısı ve bölgeye düzenlenen tur ve gezi sayısına ilişkin verilerin internet üzerinden elde edilmesi araştırmanın sinırlılıkları arasında yer almaktadır. Ayrıca çalışmada belirlenen alternatiflere bireysel ziyaretler dahil edilmemiş, grup gezileri ve turlar üzerinden hesaplama yapılmıştır. $\mathrm{Bu}$ çalışmada değerlendirilen sekiz kriterin yanı sıra gelecek çalışmalarda farklı alanlara özgü değerlendirme kriterleri kullanılabilir. Bununla birlikte ÇKKV tekniklerinin yanı sıra faklı araştırma desenleri ile söz konusu durum araştırılabilir.

Hakem Değerlendirmesi: Dış bağımsız.

Çıkar Çatışması: Yazarlar çıkar çatışması bildirmemiştir.

Finansal Destek: Yazarlar bu çalışma için finansal destek almadığını beyan etmiştir.

Peer-review: Externally peer-reviewed.

Conflict of Interest: The authors have no conflict of interest to declare.

Grant Support: The authors declared that this study has received no financial support.

\section{KAYNAKCAA/REFERENCES}

Akten, S. ve Gül, A. (2014). Korunan doğal alanlarda ziyaretçilerin olası etki düzeyleri önlem ve standartların belirlenmesi (Gölcük Tabiat Park1 örneği). Türkiye Ormancılık Dergisi, 15(2), 130-139.

Arat, T. ve Çalımlı, Y. (2019). Turizm endüstrisinde sürdürülebilir kalkınma için eko turizmin önemi: Konya'da bir araştırma. Çatalhöyük Uluslararası Turizm ve Sosyal Araştırmalar Dergisi, 3, 23-39.

Avcı, N. (2007), Turizmde taşıma kapasitesinin önemi. Ege Akademik Bakış/ Ege Academic Review, 7(2), 485-501.

Baležentis, T., \& Baležentis, A. (2014). A survey on development and applications of the multi-criteria decision making method MULTIMOORA. Journal of Multi-Criteria Decision Analysis, 21(3-4), 209-222.
Brauers, W. K. M., \& Zavadskas, E. K. (2010). Project management by MULTIMOORA as an instrument for transition economies. Technological and Economic Development of Economy, 16(1), 5-24.

Brauers, W. K. M., \& Zavadskas, E. K. (2006). The MOORA method and its application to privatization in a transition economy. Control and Cybernetics, 35, 445-469.

Brauers, W. K. M., \& Zavadskas, E. K. (2009). Robustness of the multiobjective MOORA method with a test for the facilities sector. Technological and Economic Development of Economy, 15(2), 352375.

Cinnioğlu, H. (2015). Sürdürülebilir ekonomik kalkınma kapsamında ekoturizmin çevre üzerindeki etkilerinin eleştirel bir bakış açısıyla incelenmesi. Sosyal Bilimler Metinleri, 1, 1-22.

Çakır, E. (2017). Kriter ağırlıklarının SWARA-Copeland yöntemi ile belirlenmesi: Bir üretim işletmesinde uygulama. Adnan Menderes Üniversitesi Sosyal Bilimler Enstitüsü Dergisi, 4(1), 42-56.

Çavuş, Ş. (2002), Turistik merkezlerin taşıma kapasiteleri ile yaşam evreleri arasındaki ilişkiler ve Kuşadası örneğinde değerlendirme. (Yayınlanmamış Doktora Tezi). Dokuz Eylül Üniversitesi Sosyal Bilimler Enstitüsü, İzmir.

Dehoorne, O., \& Tătar, C. (2013). Ecotourism development strategies for Caribbean tourism destinations. Tourismos: An International Multidisciplinary Journal of Tourism, 8(1), 283-299.

Demir, C. (2002). Turizm ve rekreasyon faaliyetlerinin olumsuz çevresel etkileri: Türkiye'deki milli parklara yönelik bir uygulama. Dokuz Eylül Üniversitesi Íktisadi ve İdari Bilimler Fakültesi Dergisi, 17(2), 93-117.

Demir, C. ve Çevirgen, A. (2006). Ekoturizm yönetimi. İzmir: Nobel Yayın Dağıtım.

Dief, M. E., \& Font, X. (2010). The determinants of hotels' marketing managers' green marketing behaviour. Journal of Sustainable Tourism, 18(2), 157-174.

Doğan, T. (2012). Turizm ve çevre ilişkisi bağlamında ekoturizmin çevre üzerine etkileri. (Uzmanlık Tezi). T.C. Kültür ve Turizm Bakanlığı Dış İlişkiler ve Avrupa Birliği Koordinasyon Dairesi Başkanlığı, Ankara.

Eltan, C., Özügül, M. D. ve Atabay, S. (2016). Uludağ Milli Parkı doğal eşiklerinin belirlenmesi. Ormancılık Araştırma Dergisi, 1(3A), 5061.

Ergün, Y. (2006). Doğada yaşamın temel kuralları. Y. Ergün (Ed.) Hatay'da On Sicak Gün içinde (s. 50-54). Hatay: Mustafa Kemal Üniversitesi Yayınlar1.

Erken, K., Atanur, G. ve Tanrı̈ver, A. A. (2019). Bursa florasının doğa turizmi potansiyeli. Artvin Çoruh Üniversitesi Orman Fakültesi Dergisi, 20(1), 92-101.

Ersöz F., ve Atav A. (2011, Temmuz). Çok kriterli karar verme problemlerinde Moora yöntemi. 31.Ulusal Yöneylem Araştırmas1 ve Endüstri Mühendisliği Kongresi’nde sunulan bildiri. Sakarya Üniversitesi, Sakarya.

Ertürk, H. (2009). Çevre Bilimleri. Bursa: Ekin Yayınları. 
Genç, T. ve Masca, M. (2013). Topsis ve Promethee yöntemleri ile elde edilen üstünlük sıralamalarının bir uygulama üzerinden karşılaştırılması. Journal of Economics \& Administrative Sciences/ Afyon Kocatepe Üniversitesi Iktisadi ve Idari Bilimler Fakültesi Dergisi, 15(2), 539-566.

Gül, A. ve Akten, M. (2005, Eylül). Korunan doğal alanlarda rekreasyonel taşıma kapasitesi ve kavramsal yaklaşımlar. Korunan Doğal Alanlar Sempozyumu'nda sunulan bildiri. Süleyman Demirel Üniversitesi, Isparta.

Gülez, S. (1989), Park-Bahçe ve Peyzaj Mimarisi. KTÜ Orman Fakültesi. Ders Notu:29, Trabzon.

Hashemkhani Zolfani, S., \& Saparauskas, J. (2013). New application of SWARA method in prioritizing sustainability assessment indicators of energy system. Engineering Economics, 24(5), 408-414.

Inskeep, E. (1991), Tourism planning. An integrated and sustainable development approach. New York: Van Nostrand Reinhold.

Ipekci Cetin, E., \& Icigen, E. T. (2017). Personnel selection based on step-wise weight assessment ratio analysis and multi-objective optimization on the basis of ratio analysis methods. World Academy of Science, Engineering and Technology, International Journal of Social, Behavioral, Educational, Economic, Business and Industrial Engineering, 11(11), 2538-2542.

Kalibatas, D., \& Turskis, Z. (2008). Multicriteria evaluation of inner climate by using MOORA method. Information Technology and Control, 37(1), 79-83.

Keršulienė, V., \& Turskis, Z. (2011). Integrated fuzzy multiple criteria decision making model for architect selection. Technological and Economic Development of Economy, 17(4), 645-666.

Keršuliene, V., Zavadskas, E. K., \& Turskis, Z. (2010). Selection of rational dispute resolution method by applying new step-wise weight assessment ratio analysis (SWARA). Journal of Business Economics and Management, 11(2), 243-258.

Kızılırmak, İ. (2011). Dünyada ve Türkiye'deki turizm işletmelerinde çevre korumaya yönelik uygulamalar: Amacı ve önemi. Sosyal Bilimler Dergisi, 2, 1-12.

Kiper, T. ve Arslan, M. (2007). Anadolu'da doğa turizmi kapsamında doğa yürüyüşü güzergahlarının belirlemesinde örnek bir çalışma. Tekirdă̆ Ziraat Fakültesi Dergisi, 4(2), 165-174.

Kozak, N., Kozak, M. A. ve Kozak, M. (2015). Genel Turizm: IllkelerKavramlar (16. bs). Ankara: Detay Yayıncılık.

Kracka, M., Brauers, W. K. M., \& Zavadskas, E. K. (2010). Ranking heating losses in a building by applying the MULTIMOORA. Engineering Economics.-Kaunas, 21(4), 352-359.

Külekci, E. A., \& Bulut, Y. (2016). Evaluation of plant that landscape value of carry some cover plants tourism potential flora in Oltu and Olur district. Iğdır Üniversitesi Fen Bilimleri Enstitüsü Dergisi, 6(1), 95-105.

Manavoğlu, E. (2009). Şehir planlama ve tasarımında su kaynaklarının önemi Antalya-Konyaaltı örneği. Planlama TMMOB Şehir Plancıları Odası Yayını, 3(4), 119-130.
McLachlan, A., Defeo, O., Jaramillo, E., \& Short, A. D. (2013). Sandy beach conservation and recreation: guidelines for optimising management strategies for multi-purpose use. Ocean \& Coastal Management, 71, 256-268.

MPA News, (2004). Assessing the carrying capacity of MPAs: how many visitors can your MPA hold. MPA News, 6(2), 1-6.

Ömürbek, N. ve Mercan, Y. (2014). İmalat alt sektörlerinin finansal performanslarının TOPSIS ve ELECTRE yöntemleri ile değerlendirilmesi. Çankırı Karatekin Üniversitesi İktisadi ve İdari Bilimler Fakültesi Dergisi, 4(1), 237-266.

Önay, O. (2018). MOORA. B. F. Yıldırım ve E. Önder (Ed.) Çok kriterli karar verme yöntemleri (3.bs) içinde (s. 245-253). Bursa: Dora Yayınc1lik.

Önay, O. ve Çetin, E. (2012). Turistik yerlerin popülaritesinin belirlenmesi: Istanbul örnegi. Isletme Iktisadi Enstitüsü Yönetim Dergisi, 72, 90-109.

Özbek, A. (2017). Çok kriterli karar verme yöntemleri ve Excel ile problem çözümü (1. bs). Ankara: Seçkin Yayıncılık.

Özdemir, G. (2007). Destinasyon yönetimi ve pazarlama temelleri: İzmir için bir destinasyon model önerisi. (Doktora Tezi). Dokuz Eylül Üniversitesi Sosyal Bilimler Enstitüsü, İzmir.

Özkan, B. (2001). Kentsel rekreasyon alan planlamas1. Ege Üniversitesi Ziraat Fakültesi Peyzaj Mimarlı̆̆ Bölümü, Ders Notu, İzmir.

Özmen, N. (2020). Sürdürülebilir turizm kapsamında turizm işletmelerinin çevre duyarlılı̆̆ının belirlenmesi: Safranbolu örneğ $i$ (Doktora Tezi). Karabük Üniversitesi Lisansüstü Eğitim Ensitütüsü, Karabük.

Pelit, E., Baytok, A. ve Soybalı, H. H. (2015). Sürdürülebilir turizm mi? Turizmde sürdürülebilirlik mi? Kavramsal bir tartışma. Gümüşhane Üniversitesi Sosyal Bilimler Elektronik Dergisi, 6 (14), 39-58.

Pils, M., Glauser, P., \& Siegrist, D. (1996). Green paper on the Alps. Bern: Nature Friends International.

Saarinen, J. (2006). Traditions of sustainability in tourism studies. Annals of Tourism Research, 33(4), 1121-1140.

Sakarya, Y. (2000). Orman içi dinlenme yeri planlaması, Ankara: Milli Parklar ve Yaban Hayatı Genel Müdürlüğü Personeli Güçlendirme Vakfi Yayınları. Yayın No: 002.

Sert, A. N. (2017). Konaklama işletmelerinde yeşil pazarlama uygulamalar1: Doğa Residence Otel örneği. Türk Turizm Araştırmaları Dergisi, 1(1), 1-20.

Seyhan, G. ve Y1lmaz, B. C. (2010). Sürdürülebilir turizm kapsamında konaklama işletmelerinde yeşil pazarlama; Calısta Luxury Resort Hotel, Issletme Fakültesi Dergisi, 11(1), 51-74.

Sılaydın, M. B. (2007). Șehir planlama ve su kaynakları ilișkisi: Mevcut durum, sorunlar ve öneriler (İzmir deneyimi). Planlama TMMOB Şehir Plancıları Odası Yayını, 3(4), 111-117.

Silva, J. N., \& Ghilardi-Lopes, N. P. (2012). Indicators of the impacts of tourism on hard-bottom benthic communities of Ilha do Cardoso State Park (Cananéia) and Sonho Beach (Itanhaém), two southern coastal areas of São Paulo State (Brazil). Ocean \& Coastal Management, 58, 1-8. 
Simon, F. J. G., Narangajavana, Y., \& Marques, D. P. (2004). Carrying capacity in the tourism industry: a case study of Hengistbury Head. Tourism Management, 25(2), 275-283.

Şahin, C. D. (2016). Oteller bazında su tüketiminin cbs yardımıyla belirlenmesi; İstanbul örneği. (Doktora Tezi). İstanbul Teknik Üniversitesi Fen Bilimleri Enstitüsü, İstanbul.

Tomar, A. (2009). Toprak ve su kirliliği ve su havzalarının korunmast. TMMOB İzmir Kent Sempozyumu'nda sunulan bildiri. İzmir.

Tuncer, M. ve Çavuş, S. (2017). Gelişen turizm destinasyonlarından biri olarak Aksaray ilinin alternatif turizm potansiyelinin belirlenmesine yönelik bir araştırma. Erzincan Üniversitesi Sosyal Bilimler Enstitüsü Dergisi (ERZSOSDE) ÖS-IV, 51-60.
Yalçın Özdilek, Ş. (2006). Derin Ekoloji. Y. Ergün (Ed.) Hatay'da On Sıcak Gün içinde (s. 106-110). Hatay: Mustafa Kemal Üniversitesi Yayınları.

Yurdoğlu, H. ve Kundakc1, N. (2017). SWARA ve WASPAS yöntemleri ile sunucu seçimi. Balıkesir Üniversitesi Sosyal Bilimler Enstitüsü Dergisi, 20(38), 253-269.

Yüksek, T., Cengiz, T. ve Yüksek, F. (2008). Doğal alanlarda festival etkinliklerinin koruma kullanma açısından değerlendirilmesi: Kafkasör Kültür, Sanat ve Turizm Festivali örneği. Ekoloji Dergisi, 17, 37-45. 
